\title{
An Analysis of Products Communicated on Instagram by the Most followed Czech Influencers
}

\author{
Kateřina Kvěchová ${ }^{1, *}$ \\ ${ }^{1}$ Institute of Technology and Business, Faculty of Corporate Strategy, Department of Tourism and Marketing, Nemanická 436/7, \\ 37010 České Budějovice, Czech Republic
}

\begin{abstract}
The aim of this contribution is to determine and analyse the types of products the five most followed Instagram influencers in the Czech Republic promoted during the period September 2019 September 2020. The most followed influencers in 2020 were identified on the basis of the highest number of followers (Leoš Mareš, Petr Čech, Jirka Král, Karolina Kurková and Anna Šulcová). The next step was to calculate the frequency of product-related posts by each influencer according to the individual product types. Based on the data, it can be concluded that the most frequent product-related posts are associated with clothing and accessories, followed by magazines, cosmetics, e-shops, sports, travel, culture, children's goods or restaurants.
\end{abstract}

Keywords: influencer marketing; influencer; product-related posts; communication; Instagram

\section{Introduction}

One of the influencer agencies states that the amount of funding spent in this area in 2018 was $\$ 4-7$ billion [1]. Other available sources predict further growth in investment in this area. This prediction is confirmed by the fact that in 2018 the number of Instagram users exceeded one billion for the first time. Influencer marketing is part of online marketing, which is one of the fastest growing forms of marketing. In other sources, it has been proven that advertising inspires only $30 \%$ of users, whereas the trust followers have in influencers is $95 \%$. It is clear from past developments in the industry that the gap between these numbers will widen even further in the future [2].

It is stated that the Internet population of the Czech Republic (older than ten years) reached 7.8 million people in September 2019, of which 5.3 million users connected to the Internet via a mobile device [3]. According to the CZSO [4] the total volume of social network users in the Czech Republic in 2019 was 4.735 million. Various studies have shown that Czechs spend the most time on the Facebook (59\% of respondents), followed by Seznam, YouTube, Google and Instagram [5].

Data from the Czech Republic show that in September 2019 Instragram was used by 2,275,000 users, of which the largest group (730,000 users) were people aged 18-24 years [6].

The above data show that social networks atttract many users from different segments, so there is great potential for a broad marketing communication mix. In 2019 , in the US, over $60 \%$ of companies increased their influencer promotion budgets [7]. The worldwide trend is to move advertising from Facebook to Instragram. The advantage of Instragram is the higher interaction on product-related posts, as well as the wide community network of users. Current trends show that consumers are more likely to determine their purchasing behaviour based on the reviews and references of influencers that they follow [8].

Based on the highest number of followers of foreign influencers, the worldwide trend in communication on Instragram is mainly focused on clothing, cosmetics, catering, travel, culture and sports.

In the last few years, taking advantage of influencers on social networks has become an increasingly popular advertising strategy for brands looking to promote products, especially when targeting younger demographic groups. The results show that the informative value of influencer-generated content, influencer credibility, attractiveness, and similarity with followers positively affects their confidence in the product-related posts, which in turn affects brand awareness and purchasing intentions [9].

It has been shown that there should be ongoing cooperation between companies and influencers, in order to achieve better creative results [10]. Kumar, Aksoy and Donkers [11] proposed four components of the perception of the value of the customer's commitment to a company. These are the lifetime value of the customer (customer shopping behaviour),

\footnotetext{
* Corresponding author: kvechova@mail.vstecb.cz
} 
the value of the customer's recommendation, the value influencing the customer (which includes the customer's behaviour with regards to influencing other customers), and the knowledge value for the customer. The findings reveal that Instagram product-related posts about highly trusted brands have a positive impact on its credibility, access to advertising and intention to purchase by followers [12].

The developing influencer community therefore has considerable power over brand perception, and society can greatly affect its reputation. These new features require communication professionals to seek continuous collaboration through various social web channels [13]. Jin, Mugaddam and Ryu [14] have even shown that consumers exposed to Instagram celebrity product-related posts perceive the source as more credible, show a more positive attitude towards the supported brand, feel their social rank improves, compared to consumers exposed only to celebrities.

Influencers who publish recommendations on original products and therefore have no commercial relationship with the brand are also successful if they explicitly state this [15]. The acquired credibility of influencers clearly shows significant and positive relationships to the purchasing intention [16].

In addition, they found that the reduction in interest was more pronounced in influencers than in branding. These facts suggest that the commercial orientation of a promotion has a strong negative impact on how it is perceived, reduces confidence in the influencer and also reduces the credibility of the product-related posts [17].

Chetioui et al. [18] demonstrate that perceived credibility, perceived behavioural control, perceived subjective norms, perceived expertise, and perceived compliance positively influences attitudes toward fashion influencers. Conversely, for organic products, for example, influencers want folllowers to believe in the ecology of a product only on the basis of a statement they make in their account [19]. On the contrary, in tourism, an important factor in an influencer's success is being loyal to one's self, the brand and their audience [20]. For fashion influencers, success factors are not only credibility but also the social and physical attractiveness of the influencers [18]. Like for fashion product-related posts, similar requirements apply to influencers in the cosmetics sector, whereby Instagram is becoming an increasingly important tool for placing products or services [21].

Curiel [22] examined the impact of the communication model on digital social media users in policy-oriented productrelated posts. He performed a quantitative-qualitative comparative content analysis and confirmed the impact of strategic marketing tools on the response rate of social media users. The same research method was applied to the field of fashion. The results of the study showed that the application of strategic tools can restore a company's image and brand popularity [23].

The data examined clearly show that influencer marketing has a positive effect on consumer involvement in brand communication, influence on brand choice, shaping brand perception and improving customer willingness to publish brand promotional content [24].

\section{Methodology}

The aim of this contribution is to determine and analyse the types of products the five most followed Instagram influencers in the Czech Republic promoted during the period September 2019 - September 2020. Based on the aim, two research questions were determined:

1. In the last year, what were the ten most frequently promoted products via product-related posts on Instagram by the five most followed influencers in the Czech Republic?

2. Were the product-related posts of the five most followed influencers in the Czech Republic targeted at the relevant consumer segment?

The most followed influencers in 2020 were identified on the basis of a published list [25]. The analysed influencers were identified on the basis of the highest number of followers. The football player Petr Čech has the highest number of followers $(2,062,470)$, followed by presenter Leoš Mareš $(1,079,795)$, YouTuber Jirka Král $(902,903)$, the model Karolína Kurková (810,965, who was born in the Czech Republic but lives in the USA, and Anna Šulsová (829,927). Furthermore, for each monitored influencer, the history of product-related posts from September 2019 to September 2020 was analysed. The next step was to calculate the frequency of product-related posts for each influencer according to individual product types. Based on the frequency of product-related posts for a given product type by the analysed influencers, the ten most frequently promoted products were determined.

After determining the most frequently communicated products by each influencer, heuristic methods were applied to determine whether the products communicated by the influencer corresponded to their target segment, i.e. their followers. The follower segment was determined according to research conducted by a marketing agency [26]. Heuristic methods provided an approximate solution based on the author's expert judgment and experience. 


\section{Results and discussion}

The analysis of the product-related posts of the most followed influencers took place over a one year period (from September 2019 to September 2020), whereby each valid influencer post had to be product related.

At the time of analysis, Petr Čech had the most followers $(2,062,470)$. Petr Čech posted a total of 23 product-related posts during the monitored period. Most of the posts were focused on sports equipment (13), in particular for football (Table 1).

Table 1. Petr Čech - product-related posts

\begin{tabular}{|c|c|}
\hline \multicolumn{2}{|c|}{ Petr Čech $(\mathbf{2 , 0 6 2 , 4 7 0}$ followers $)$} \\
\hline Product type* & Frequency of appearance \\
\hline Sport & 13 \\
\hline Clothes, accessories & 1 \\
\hline
\end{tabular}

Source: Author.

(*List of represented brands: Chelsea, Euro 2020, 21 Euro, Premier League (13), Puma (1))

Table 2. Leoš Mareš - product-related posts

\begin{tabular}{|c|c|}
\hline \multicolumn{2}{|c|}{ Leoš Mareš (1,079,795 followers) } \\
\hline Product type* & Frequency of appearance \\
\hline Retail & 24 \\
\hline Restaurants, cafes & 10 \\
\hline Foodstuffs & 5 \\
\hline Clothes, accessories & 2 \\
\hline Cosmetics & 2 \\
\hline Sport & 9 \\
\hline Magazines & 20 \\
\hline Travel, culture & 20 \\
\hline Children's goods & 5 \\
\hline TV, Radio & 12 \\
\hline
\end{tabular}

Source: Author.

(*List of represented brands: Penny (23), Thestorepraque (1), If Cafe (5), My Chef Kitchen (4), Yuniku bbq (1), Mumm (2), Bigboybutter (2), Tostiny (1), Linda Farow (1), LV (1), Whitepear001 (2), Slavia Praha (7), Praqueplayoff (2), Forbes (3), Esquire (9), iDnes (1), Reflex (1), Elle (1), Proč ne magazin (5), The Chedi Muscat (1), Flymeto.world (4), Letiště Václava Havla (1), Ticketstream, Ticketportal (14), Trihorse (5), Mall TV (1, Evropa 2 (11))

Based on the number of followers, Leoš Mareš $(1,079,795)$ is the second most followed influencer. Table 2 shows that during the monitored period, he had a total of 142 product-related posts promoting various products. Leoš Mareš has a wide range of specializations on Instragram. Penny Market, the supermarket chain, was the most frequently communicated brand (5.7\%). This was followed by magazines and journals, travel and culture.

The third most followed influencer is Jirka Král $(902,903)$. IT technologies were the most promoted type of product in his Instragram posts. Beyond this, his posts also featured sports, restaurants and coffee shops (Table 3). Jirka Král is more active on YouTube, so the frequency of his product-related posts on Instragram is lower.

Table 3. Jirka Král - product-related posts

\begin{tabular}{|c|c|}
\hline \multicolumn{2}{|c|}{ Jirka Král (902,903 followers) } \\
\hline Product type* $^{*}$ & Frequency of appearance \\
\hline IT & 10 \\
\hline Sport & 2 \\
\hline Restaurants, cafes & 3 \\
\hline
\end{tabular}

Source: Author.

(*List of represented brands: Asus (5), GoPro (5), MMA (1), NHL (1), Z Kotva (2), Mc'Donalds (1))

The fourth most followed influencer is Karolína Kurková $(810,965)$. During the monitored period, she had a total of 168 product-related posts. Among the most common products communicated to followers were cosmetics, clothing and 
accessories and magazines (Table 4). Karolína Kurková lives in the USA, but her product-related posts are also focused on the Czech consumer.

Table 4. Karolína Kurková - product-related posts

\begin{tabular}{|c|c|}
\hline \multicolumn{2}{|c|}{ Karolína Kurková (810,965 followers) } \\
\hline Product type* & Frequency of appearance \\
\hline Magazines & 40 \\
\hline Children's goods & 10 \\
\hline E-shops & 15 \\
\hline Travel, culture & 1 \\
\hline Clothes, accessories & 42 \\
\hline Cosmetics & 43 \\
\hline IT & 1 \\
\hline Foodstuffs & 2 \\
\hline
\end{tabular}

Source: Author.

(*List of represented brands: Elle (3), Harpers bazaar (12), Forbes (1),Voque (9), Museum magazine (1), Parents (2), Stella (2), Number magazine (1), Ocean drive magazine (4), W magazine (2), Vanity fair (1), Instyle (1), Madam magazine (1) Cybex (10), Aboutyou (15), Editions (1), Billieblooms (15), Chanel (1), David Jones (3), Gucci (1), Versace (1), Tods (2), Victoria Secret (4), Prada (1), Valentino (2), Dolce a Gabbana (1), Dior (2), J. P. Gaultier (2), Donna Karan (1), Rocket (1), Oscar de la Renta (2), Hermes (1), Levis (1)Joannaczech (2), Gryphanddivyrose (36), Inner beauty (1), Theanycosmetics (1), Myskinbuddy (2), Daylisleeper (1) Leica camera (1), Beyodmeet (1), Dayilyharvest (1))

The fifth most followed influencer is Anna Šulcová $(829,927)$. This influencer had 54 product-related posts. Table 5 shows that e-shops and clothing and accessories were most often mentioned on her profile.

Table 5. Anna Šulcová - product-related posts

\begin{tabular}{|c|c|}
\hline \multicolumn{2}{|c|}{ Anna Šulcová (829 927) } \\
\hline Product type* $^{*}$ & Frequency of appearance \\
\hline E- shops & 24 \\
\hline Clothes, accessories & 21 \\
\hline Cosmetics & 1 \\
\hline Travel, culture & 2 \\
\hline Cars & 3 \\
\hline
\end{tabular}

Source: Author.

(*List of represented brands: Zalando (23), Kup kosmetiku (1), Tezenis (11), DW a FP (3), JVD Forher (4), Honor (1), Prada a Max Mara (2), Batiste (1), Visitbudapest (1), Saintjohnresort (1), Hyundai (3))

Table 6. Summary of product-related posts by influencers

\begin{tabular}{|c|c|c|c|}
\hline Order & Product type & Frequency of appearance & Occurrence (\%) \\
\hline 1. & Clothes, accessories & 66 & 16.3 \\
\hline 2. & Magazines & 60 & 14.8 \\
\hline 3. & Cosmetics & 46 & 11.3 \\
\hline 4. & E-shops & 39 & 9.6 \\
\hline 5. & Sport & 24 & 5.9 \\
\hline 6. & Travel, culture & 23 & 5.7 \\
\hline 7. & Children's goods & 15 & 3.7 \\
\hline 8. & Restaurants, cafes & 13 & 3.2 \\
\hline 9. & IT & 11 & 2.7 \\
\hline 10. & Foodstuffs & 7 & 1.7 \\
\hline 11. & Other & 78 & 19.2 \\
\hline Special & Retail & 24 & 5.9 \\
\hline
\end{tabular}

Source: Author. 
Table 6 shows the most frequently promoted products according to the frequency of product-related posts for the given product type. For each product type, it was desirable for the product type to be promoted by more than one influencer. For example, Leoš Mareš' product-related posts concerning Penny Market (retail trade) did not meet the aforementioned condition. The influencer was the only one to communicate this type of product, but the frequency was relatively significant (5.7\%). Tabel 6 shows that the most frequent product-related posts were for clothing and accessories $(16.3 \%)$, followed by magazines $(14.8 \%)$, consumer cosmetics $(11 \%)$, e-shops $(9.6 \%)$ and sports, travel and culture $(\sim 6 \%)$. Although cars were promoted in product-related posts by at least two influencers, the frequency of this collaboration was low (4 out of 406 posts). The latter point also applies to other product types which were promoted by only one influencer and where the frequency of occurrence was at most in the order of units.

Research by a marketing agency [26] determined that the most active users of Instagram are the age group 18-24 years, followed by 25-34 years. Petr Čech's product-related posts are most often focused on sports, especially football. These product-related posts are interesting for both these segments of followers. Of all his product-related posts, Leoš Mareš most frequently mentioned retail chains, for example Penny Market. In this case, the targeting was not appropriate. For the age groups which are the most frequent followers of influencers, Penny Market is not an object of interest. His other product-related posts focused on products such as magazines, travel, restaurants and cafes, which are suitable for this type of communication. Jirka Král's product-related posts were most often focused on IT technologies, which is a matter of course for both age groups. For Karolina Kurková, product-related posts on Instragram were most often focused on cosmetics, clothing, accessories and magazines. All the products target the younger generation, so these productrelated posts are appropriate. Anna Šulcová mostly communicated about e-shops, clothes and accessories, which are also appropriate to both target groups.

Tafesse and Wood [27] examined how elements of the content of product-related posts and influencers involvement strategies contribute to the engagement of followers on Instagram. In the research they conducted, the focus of influencers' product-related posts was also determined. Based on a comparison of the results of both analyses, we can state that the most followed Czech influencers focus on similar types of products, especially clothing, cosmetics, travel, children's goods and food. Tafesse and Wood's research [27] also mentioned the following product-related posts on Instragram: weddings, luxury goods and design.

\section{Conclusion}

The aim of this contribution was to determine and analyse the types of products the five most followed Instagram influencers in the Czech Republic promoted during the period September 2019 - September 2020. The influencers were identified on the basis of the highest number of followers. The identified top five were football player Petr Čech with 2,062,470 followers, presenter Leoš Mareš with 1,079,795 followers, YouTuber Jirka Král with 902,903 followers, Karolína Kurková, a model born in the Czech Republic but living in the USA, with 810,965 followers, and Anna Šulcová with 829,927 followers. Leoš Mareš had the widest range of communication on Instragram. During the monitored period, he had a total of 142 product-related posts that promoted various products. Model Karolina Kurková had 54 productrelated posts promoting mainly e-shops, clothing, accessories and cosmetics. Petr Čech posted a total of 23 productrelated posts mainly focused on sports equipment, especially football. The most active users of Instagram are the age group 18-24 years, followed by 25-34 years. The product-related posts of Petr Čech are interesting for both groups of followers. Of all the product-related posts, Leoš Mareš mostly mentioned retail chains, in particular Penny Market. In this case, the targeting was not appropriate. His other product-related posts were appropriate to the target groups and focused on products such as magazines, travel, restaurants and cafes. Likewise, Jirka Král's product-related posts were most often focused on IT technologies, which is a matter of course for both age groups. Anna Šulcová most often communicated about e-shops, clothes and accessories, both of which are appropriate to the target groups.

\section{References}

1. Get Boost - Influencer marketing \& Social media marketing agentura. Influencer marketing [online]. Available at: https://www.getboost.cz/influencer-marketing/ (2020)

2. PROMOPRODUKCE CZ. 5 věcí, které musíte vědět o influencer marketingu [5 things you need to know about influencer marketing]. [online]. Available at: https://www.webfin.cz/5-veci-ktere-musite-vedet-o-influencermarketingu (2020)

3. SPIR. Internetová populace $\check{C} R$ dosáhla v březnu nového maxima: 7,77 milionu reálných uživateli̊ [The Internet population of the Czech Republic reached a new maximum in March: 7.77 million real users]. [online] Available at: $\quad$ https://www.spir.cz/internetova-populace-cr-dosahla-v-breznu-noveho-maxima-7-77-milionu-realnychuzivatelu (2020)

4. ČSÚ. Sociální sítě [Social networks]. [online]. Available at: https://www.czso.cz/csu/czso/7-vyhledavanivybranych-informaci-na-internetu-491bfx37fh (2020) 
5. KANTAR - Česká republika. KANTAR - Česká republika [KANTAR - Czech Republic]. [online]. Available at: https://cz.kantar.com/ (2020)

6. BUSINESSGRAM. Počet lidí na českém a slovenském Instagramu k záři 2019. Jsme jednička ve školení firemního Instagramu na českém trhu [Number of people on the Czech and Slovak Instagram as of September 2019. We are number one in corporate Instagram training on the Czech market]. [online]. Available at: https://businessgram.eu/pocet-lidi-na-ceskem-a-slovenskem-instagramu-zari-2019/ (2019)

7. eMarketer. Is Everyone on Instagram an Influencer? [online]. Available at: https://www.emarketer.com/content/iseveryone-on-instagram-an-influencer (2020)

8. Marketing \& Media. Trendy a data na sociálních sitích podle Socialbakers [Trends and data on social networks by Socialbakers]. [online]. Available at: https://mam.cz/marketing/2019-12/trendy-a-data-na-socialnich-sitich-podlesocialbakers/ (2020)

9. L. Chen, S. Yuan, Influencer marketing: how message value and credibility affect consumer trust of branded content on social media. Journal of Interactive Advertising. 19(1), 58-73 (2019)

10. L. Casaló, C. Flavián, S. Ibáñez-Sánchez, Influencers on Instagram: Antecedents and consequences of opinion leadership. Journal of Business Research. 117, 510-519 (2018)

11. V. Kumar et al. Undervalued or overvalued customers: capturing total customer engagement value. Journal of service research. 13(3), 297-310 (2010)

12. S. Lee, E. Kim, Eunice. Influencer marketing on Instagram: How sponsorship disclosure, influencer credibility, and brand credibility impact the effectiveness of Instagram promotional product-related post. Journal of Global Fashion Marketing. 11(3), 232-249 (2020)

13. J. Vodák, et al. Influencer Marketing as a Modern Phenomenon in Reputation Management. Managing Global Transitions. 17(3), 211-220 (2019)

14. S. V. Jin, A. Muqaddam, E. Ryu, Instafamous and social media influencer marketing. Marketing Intelligence \& Planning. 37(5), 567-579 (2019)

15. M. De Weirman, V. Cauberghe, L. Hudders, Disclosing sponsored Instagram product-related posts: the role of material connection with the brand and message-sidedness when disclosing covert advertising. International journal of advertising. 39(1), 94-130 (2020)

16. K. Sokolova, H. Kefi, Instagram and YouTube bloggers promote it, why should I buy? How credibility and parasocial interaction influence purchase intentions. Journal of Retailing and Consumer Services. 53 (2020)

17. F. J. Martínez-López, R. Anaya-Sánchez, M. F. Giordano, D. Lopez-Lopez, Behind influencer marketing: key marketing decisions and their effects on followers' responses. Journal of Marketing Management. 36(7-8), 579607 (2020)

18. Y. Chetioui, H. Benlafgih, H. Lebdaoui. How fashion influencers contribute to consumers' purchase intention. Journal of Fashion Marketing and Management: An International Journal. In print (2020)

19. M. Söderlund, J. Mattsson, Consumers reactions to unsubstantiated claims about ecological products. Journal of Consumer Marketing. 37(5), 569-578 (2020)

20. M. L. Wellman, R. Stoldt, M. Tully, et al. Ethics of Authenticity: Social Media Influencers and the Production of Sponsored Content. Journal of Media Ethics. 35(2), 68-82 (2020)

21. E. Villena Alarcón, M. Jesus Fernandez-Torres, Relaciones con los públicos a través de Instagram: los influencers de belleza como caso de estudio/Beauty on Instagram: Relations between influencers and the stakeholders. Revista Internacional de Relaciones Públicas. 10(19), 111-132 (2020)

22. C. P. Curiel, Trend towards extreme right-wing populism on Twitter. An analysis of the influence on leaders, media and users. Communication \& Society. 33(2), 175-192 (2020)

23. C. P. Curiel, P. Sanz-Marcos, Branding, influencers and new target in the communication of fashion and luxuary the Gucci tendency on Instragram. Prisma Social. 24, 1-24 (2019)

24. C. Stubb, AG NystrÖm, J. Colliander, Influencer marketing. Journal of Communication Management. 23(2), 109$122(2019)$ 
25. Mzone. TOP 10 českých influencerů: Kdo má kolik sledujících na Instagramu? Někteři překvapí! [TOP 10 Czech influencers: Who has how many followers on Instagram? Some will surprise you!]. [online]. Available at: https://www.mzone.cz/instagram-top-10-ceskych-influenceru/ (2020)

26. Dantoa. Facebook vs. Instagram - proč se většina konverzí odehrává na Facebooku? [Facebook vs. Instagram - why do most conversions take place on Facebook?]. [online]. Available at: https:/www.dantoa.cz/facebook-vsinstagram-proc-se-vetsina-konverzi-odehrava-na-facebooku/ (2020)

27. W. Tafesse, P. B.Wood, Followers' engagement with instagram influencers: The role of influencers' content and engagement strategy. Journal of Retailing and Consumer Services. 58 (2021) 